\title{
Antarctic Glacier Monitoring
}

\author{
PRAKASH K SHRIVASTAVA*, SANDIP K ROY and HAMZA Y BHAI \\ Polar Studies Division, Geological Survey of India, Faridabad 121 001, India
}

(Received on 24 August 2016; Accepted on 29 November 2016)

\begin{abstract}
Polar ice is an important component of the natural system, affecting global climate on large as well as small scale. The Antarctic ice sheet has undergone significant changes in the past and governed the earth's climatic system. This ice sheet appears to have been very dynamic and yet, not much is known about the processes involved for this dynamism.

Glaciological studies in parts of Central Donning Maud Land (cDML) of East Antarctica include monitoring the changes of Antarctic ice sheet overriding the Schirmacher Oasis, measurement of snow accumulation on the ice sheet, study of subsurface topography and ice sheet dynamics. In the last three decades, Dakshin Gangotri (DG) glacier snout, which is a part of East Antarctic Ice sheet (EAIS) overriding Schirmacher Oasis shows continuous recession. There are major peaks of recession in every five year cycle. The higher average annual surface air temperature leads to the greater recession in the next year. Interestingly, this recessional trend of DG snout does not show perfect correlation with the meteorological parameters (such as surface air temperature, ground temperature, wind speed, etc.) of this area. This all reflect towards the existence of very complex equation for the recession of ice sheet and snow and ice characterization in this part of Antarctica. The vector component of ice sheet shows differential movement all along the southern edge of Schirmacher Oasis. The average annual recession of snout has shown positive correlation with the mean annual runoff and negative correlation with annual mass balance of the area.
\end{abstract}

Keywords: Recession; Snow Accumulation; Mass Balance; Schirmacher Oasis; East Antarctica

\section{Introduction}

An integrated approach has been adopted by the Geological Survey of India (GSI) for carrying out glaciological studies in the area surrounding Schirmacher Oasis in central Dronning Maud Land (cDML), East Antarctica (Fig. 1) since the inception of Indian Antarctic program in 1981. These studies include yearly measurements of the changes in polar glacier front and accumulation/ablation over ice sheet and ice shelf for obtaining information on the state of the polar ice sheet vis-a-vis the impact of climate change (Singh et al., 1988; Chaturvedi et al., 2009; Shrivastava et al., 2011; Swain et al., 2011, 2012). Ground Penetrating Radar surveys have been undertaken in selected areas to understand the subsurface ice characteristics and ground configuration (Dharwadkar et al., 2012). Dakshin Gangotri (DG) glacier snout was identified during the second Indian Antarctic Expedition and since then it is being monitored regularly by the GSI. The routine glaciological observations include monitoring of the DG glacier snout and its western flank along with recording of annual accumulation/ablation of snow on the ice shelf and on ice sheet. The snow accumulation/ablation study has been recently initiated in the Larsemann Hills area also. The present write up explains the overall glaciological observations taken by GSI in parts of cDML area, south of Schirmacher Oasis, East Antarctica.

\section{Methodology}

The overall work on glaciological studies in Schirmacher Oasis and Larsemann Hills areas by the GSI includes identification of area with the help of satellite images and available literature. This is followed by sub-surface characterization of ice sheet of the selected areas with the help of Ground Penetrating Radar (GPR). The GPR system

*Author for Correspondence: E-mail: pks.shri@gmail.com 


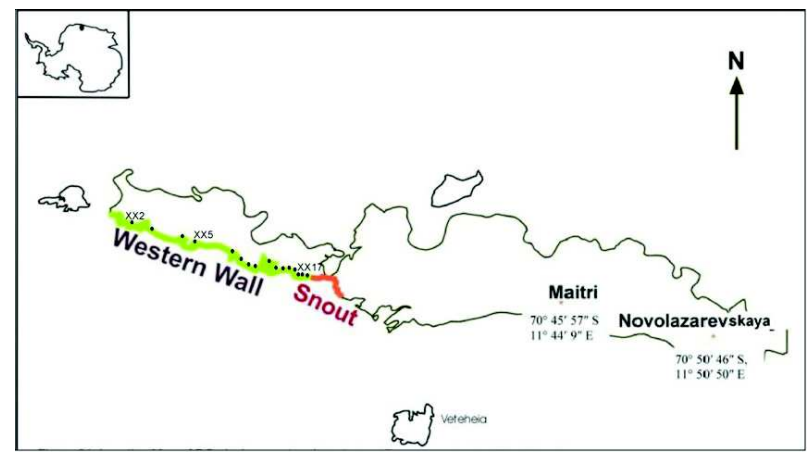

Fig. 1: Location Map of Dakshin Gangotri snout and Western wall in Schirmacher Oasis, East Antarctica

comprises a Subsurface Interface Radar (SIR) with a Toughbook, GPS, Survey wheel, cables and various antennas of 15, 20, 35, 40, 80, 100 and $200 \mathrm{MHz}$ frequency. The system was run in continuous static mode generating a continuous subsurface profile along the traverse line. When running in continuous mode, the antennas were dragged at a constant speed and the profiles were pegged to ground surface using calibrated survey wheel as well as a handheld GPS unit. The dielectric constant for ice, confirmed by velocity analysis using the common midpoint survey, was kept at 3.0. The GPR study has been used to delineate the Land-Ice-Sea (LIS) interfaces. Regular monitoring of annual snow accumulation/ablation is being carried out by stake networks. The meteorological parameters of the area help in characterizing the annual changes of the part of ice sheet in East Antarctica. Calculation of vector components of ice body with D-GPS at different locations gives the idea about ice sheet dynamics. All these factors contribute in estimation of mass balance calculation.

\section{DakshinGangotri Glacier Snout and Western Wall}

The snout of DakshinGangotri (DG) glacier, overriding Schirmacher Oasis is being monitored every year since 1982. Since then, the snout has shown continuous recession. During the period 2014-15, the DG glacier snout has receded by $1.31 \mathrm{~m}$ with respect to its position from previous year (Tables 1 and 2). For the same period, the western wall has shown a recession of $2.37 \mathrm{~m}$ with respect to the previous year. The recessional data measured is the resultant of the advancement of the Polar ice sheet during Polar winter period and the net recession during the austral summer period show an increasing trend in the cumulative recession (Table 3). The meteorological data obtained for the Schirmacher Oasis were compared for annual average surface air temperature (AASAT), annual average air temperature (AAGT), Maximum surface air temperature (MSAT), annual average relative humidity (AARH), annual average precipitation (AAP), annual average wind speed (AAWS) and annual average total cloud cover (AATCC in tenths) (Swain and Raghuram, 2015). It is observed that meteorological parameters including higher average annual surface air temperature and higher wind speed results in greater recession of the snout of DG glacier snout. A similar phenomenon was observed with the relationship of annual average surface air temperature with the recession of DG glacier snout of the next year and vice versa (Shrivastava et al., 2011).

Glaciological studies conducted in the area around Schirmacher Oasis during the last three decades were helpful in deriving some meaningful patterns and charting a cause for future work. The annual recessional pattern of the DG glacier snout indicates that major recession in every five years with minor peaks at every 2-3 years interval between 19962010 period. But in the last five years the trend of the DG snout is different than the previous 15 years period (Fig. 2; Table 1). When the annual recession of the DG snout is compared with average annual surface air temperature, it does not show direct correlation, but when the recession is compared with the preceding average annual temperature, the correlation show little improvement.

Between the period of 1996 to 2011, nearly 4800 $\mathrm{m}^{2}$ area has been vacated by the shrinking snout of this glacier. This recession has led to the disappearance of about $672 \times 10^{3} \mathrm{~m}^{3}$ ice, which is equivalent to 576 $x 10^{3} \mathrm{~m}^{3}$ of water. The average annual recession of the DG Glacier does not show any linear correlation with average annual surface air temperature, average annual ground temperature and average annual wind speed (Chaturvedi et al., 2009; Shrivastava et al., 2011, Shrivastava et al., 2014). The recession of DG snout has shown good positive correlation with mean annual runoff and has shown negative correlation with annual mass balance of the area (Fig. 3).

The Western wall includes $7 \mathrm{~km}$ (approx) long ice front (including ice wall and ramps) of the western 
Table 1: DakshinGangotri glacier snout measurements (in meters) since 1996

\begin{tabular}{|c|c|c|c|c|c|c|c|c|c|c|c|c|c|c|c|c|c|c|c|c|c|c|}
\hline $\begin{array}{l}\text { OBS. } \\
\text { PTS. }\end{array}$ & $\begin{array}{c}\text { ORIG } \\
\text { PTS } \\
\text { FEB } \\
1996\end{array}$ & $\begin{array}{c}\text { FEB } \\
-97\end{array}$ & $\begin{array}{c}\text { FEB } \\
-98\end{array}$ & $\begin{array}{c}\text { FEB } \\
-99\end{array}$ & $\begin{array}{c}\text { FEB } \\
-00\end{array}$ & $\begin{array}{c}\text { FEB } \\
-01\end{array}$ & $\begin{array}{c}\text { FEB } \\
-02\end{array}$ & $\begin{array}{c}\text { FEB } \\
-03\end{array}$ & $\begin{array}{c}\text { FEB } \\
-04\end{array}$ & $\begin{array}{c}\text { FEB } \\
-05\end{array}$ & $\begin{array}{c}\text { FEB } \\
-06\end{array}$ & $\begin{array}{c}\text { FEB } \\
-07\end{array}$ & $\begin{array}{c}\text { FEB } \\
-08\end{array}$ & $\begin{array}{c}\text { FEB } \\
-09\end{array}$ & $\begin{array}{c}\text { ORIG } \\
\text { ORIG } \\
\text { FEB } \\
2009\end{array}$ & $\begin{array}{c}\text { FEB } \\
-10\end{array}$ & $\begin{array}{c}\text { JAN } \\
-11\end{array}$ & $\begin{array}{c}\text { JAN } \\
-12\end{array}$ & $\begin{array}{c}\text { JAN } \\
-13\end{array}$ & $\begin{array}{c}\text { JAN } \\
-14\end{array}$ & $\begin{array}{c}\text { FEB } \\
-15\end{array}$ & $\begin{array}{c}\text { FEB } \\
-16\end{array}$ \\
\hline 1 & 2.00 & 2.66 & 3.35 & 3.02 & 3.70 & 3.56 & 3.22 & 3.91 & 4.80 & 7.81 & 7.95 & 8.05 & 11.62 & 12.05 & $1.72 *$ & $1.80 *$ & - & - & 10.33 & - & - & - \\
\hline 2 & 4.50 & 4.93 & 7.40 & 9.10 & 10.80 & 11.10 & 11.25 & 12.19 & 13.94 & 15.65 & 15.86 & 14.50 & 17.85 & 16.87 & 1.65 & 2.09 & 2.17 & 1.98 & 3.00 & 2.76 & 4.55 & 6.42 \\
\hline $2 \mathrm{~A}$ & - & - & - & - & - & - & - & - & - & - & - & - & - & - & - & - & 2.39 & 2.30 & - & 6.15 & 6.89 & 8.7 \\
\hline 3 & 1.00 & 1.28 & 1.90 & 2.20 & 2.33 & 2.69 & 3.10 & 3.7 & 4.20 & 4.86 & 5.44 & 6.72 & 7.11 & 7.29 & 1.36 & 1.61 & 2.39 & 2.30 & 2.84 & 2.93 & 3.42 & 3.46 \\
\hline 4 & 2.00 & 1.80 & 2.83 & 3.40 & 3.72 & 4.01 & 4.35 & 4.66 & 5.33 & 5.63 & 6.29 & 6.52 & 6.80 & 6.92 & 2.00 & 2.02 & 2.40 & 2.55 & 2.76 & 2.74 & 2.99 & 3.34 \\
\hline 4-A & 2.00 & 2.19 & 2.60 & 2.85 & 3.10 & 3.46 & 3.90 & 4.27 & 4.45 & 4.65 & 4.83 & 5.24 & 5.63 & 5.84 & 2.00 & 2.37 & 2.89 & 3.05 & 3.80 & 4.19 & 5.52 & 5.8 \\
\hline 4-B & 2.50 & 2.70 & 2.95 & 3.00 & 3.40 & 3.74 & 4.05 & 4.43 & 4.33 & 4.15 & 5.27 & 5.20 & 5.63 & 5.67 & 1.78 & 2.25 & 2.80 & 2.90 & 4.10 & 4.54 & 5.69 & 5.7 \\
\hline 5 & 7.00 & 7.16 & 8.10 & 8.70 & 9.30 & 8.32 & 8.53 & 8.56 & 11.75 & 11.65 & 11.3 & 11.48 & 11.08 & 14.42 & 2.86 & 2.64 & 3.30 & 3.55 & 4.27 & 4.32 & 10.26 & 9.63 \\
\hline 5-A & 1.10 & 1.49 & 1.51 & 1.92 & 1.50 & 1.99 & 2.30 & 3.09 & 3.08 & 3.35 & 4.10 & 3.90 & 4.04 & 4.17 & 1.65 & 1.93 & 2.33 & 2.38 & 3.09 & 3.24 & 3.37 & 4.68 \\
\hline 5-B & 1.10 & 1.42 & 2.05 & 2.60 & 3.00 & 3.04 & 3.45 & 4.08 & 4.37 & 4.39 & 5.04 & 4.55 & 5.63 & 5.66 & 1.21 & 1.60 & 2.16 & 2.30 & 3.18 & 3.78 & 5.17 & 5.31 \\
\hline 6 & 1.50 & 1.36 & 1.80 & 1.96 & 2.08 & 2.92 & 4.10 & 5.06 & 6.97 & 8.55 & 10.98 & 11.55 & 14.35 & 14.70 & 2.20 & 3.13 & 3.72 & 3.30 & 5.60 & 5.80 & 6.31 & 6.61 \\
\hline 7 & 1.50 & 1.72 & 3.10 & 3.84 & 4.24 & 5.15 & 6.00 & 8.14 & 9.44 & 10.95 & 12.45 & 12.90 & 14.10 & 15.33 & 2.90 & 2.72 & 3.10 & 4.00 & 4.80 & 5.53 & 5.94 & 6.37 \\
\hline 8 & 5.00 & 5.09 & 6.40 & 6.20 & 6.98 & 6.98 & 7.96 & 8.71 & 8.00 & 9.15 & 9.52 & 10.35 & 11.09 & 11.22 & 4.22 & 4.22 & 4.36 & 4.08 & 4.87 & 4.72 & 5.32 & 5.1 \\
\hline 9 & 2.00 & 3.49 & 4.50 & 5.56 & 6.54 & 7.25 & 8.35 & 10.52 & 10.01 & 10.92 & 12.43 & 12.50 & 12.97 & 13.31 & 2.62 & 4.15 & 4.68 & 5.14 & 5.40 & 5.30 & 5.55 & 5.76 \\
\hline 10 & 4.00 & 4.10 & 4.43 & 4.47 & 6.04 & 6.61 & 6.59 & 8.32 & 8.45 & 9.05 & 9.71 & 10.20 & 10.94 & 12.32 & - & - & - & - & 13.6 & 12.54 & 14.66 & 15.5 \\
\hline $10 \mathrm{~A}$ & - & - & - & - & - & - & - & - & - & - & - & - & - & - & 1.81 & 5.23 & 5.80 & 5.62 & - & - & - & 6.43 \\
\hline 11 & 2.00 & 2.09 & 3.66 & 3.71 & 4.46 & 5.20 & 4.83 & 5.46 & 6.30 & 6.25 & 6.46 & 7.90 & 8.52 & 8.66 & 2.30 & 1.10 & 2.71 & 3.42 & 4.33 & 4.54 & 6.07 & 7.04 \\
\hline 12 & 3.50 & 5.01 & 6.15 & 6.68 & 7.01 & 7.33 & 7.99 & 8.94 & 9.88 & 10.79 & 11.34 & 12.15 & 14.36 & 15.13 & 1.82 & 1.32 & 3.30 & 3.58 & 3.62 & 3.69 & 5.44 & - \\
\hline 13 & 1.00 & 1.84 & 3.25 & 4.26 & 5.15 & 5.83 & 5.85 & 7.99 & 7.86 & 10.15 & 11.31 & 12.51 & 14.22 & 15.06 & 4.01 & 1.34 & 2.93 & 3.25 & 4.50 & 4.96 & 5.97 & 6.91 \\
\hline $14 \mathrm{~A}$ & - & - & - & - & - & - & - & - & - & - & - & - & - & - & - & - & 7.54 & 9.41 & 10.20 & 11.91 & 12.94 & 14.04 \\
\hline 14 & 1.50 & 2.22 & 4.10 & 6.06 & 8.02 & 9.34 & 10.00 & 13.32 & 15.90 & 16.10 & 18.71 & 23.74 & 23.82 & 34.76 & 2.94 & 3.59 & 4.62 & 4.64 & 5.50 & 6.17 & 6.98 & 8.09 \\
\hline 15 & 6.50 & 8.41 & 10.10 & 11.13 & 12.15 & 12.72 & 13.38 & 16.78 & 18.10 & 19.64 & 20.94 & 21.42 & 22.53 & 23.75 & 1.98 & 2.85 & 2.58 & 4.72 & 7.10 & 8.41 & 11.5 & 12.09 \\
\hline
\end{tabular}


Table 2: Average annual recession/advancement of DakshinGangotri glacier since 1997 (in metres)

\begin{tabular}{|c|c|c|c|c|c|c|c|c|c|c|c|c|c|c|c|c|c|c|c|c|c|}
\hline Year & $\begin{array}{c}1996 \\
\text { to } \\
1997\end{array}$ & $\begin{array}{c}1997 \\
\text { to } \\
1998\end{array}$ & $\begin{array}{c}1998 \\
\text { to } \\
1999\end{array}$ & $\begin{array}{c}1999 \\
\text { to } \\
2000\end{array}$ & $\begin{array}{c}2000 \\
\text { to } \\
2001\end{array}$ & $\begin{array}{c}2001 \\
\text { to } \\
2002\end{array}$ & $\begin{array}{c}2002 \\
\text { to } \\
2003\end{array}$ & $\begin{array}{c}2003 \\
\text { to } \\
2004\end{array}$ & $\begin{array}{c}2004 \\
\text { to } \\
2005\end{array}$ & $\begin{array}{c}2005 \\
\text { to } \\
2006\end{array}$ & $\begin{array}{c}2006 \\
\text { to } \\
2007\end{array}$ & $\begin{array}{c}2007 \\
\text { to } \\
2008\end{array}$ & $\begin{array}{c}2008 \\
\text { to } \\
2009\end{array}$ & $\begin{array}{c}2009 \\
\text { to } \\
2010\end{array}$ & $\begin{array}{c}2010 \\
\text { to } \\
2011\end{array}$ & $\begin{array}{c}2011 \\
\text { to } \\
2012\end{array}$ & $\begin{array}{c}2012 \\
\text { to } \\
2013\end{array}$ & $\begin{array}{c}2013 \\
\text { to } \\
2014\end{array}$ & $\begin{array}{c}2014 \\
\text { to } \\
2015\end{array}$ & $\begin{array}{c}2015 \\
\text { to } \\
2016\end{array}$ & $\begin{array}{c}1996 \\
\text { to } \\
2016\end{array}$ \\
\hline 1 & 0.66 & 0.69 & -0.33 & 0.68 & -0.14 & -0.34 & 0.69 & 0.89 & 3.01 & 0.14 & 0.10 & 3.57 & 0.43 & 0.08 & 0.37 & - & - & - & - & - & - \\
\hline 2 & 0.43 & 2.47 & 1.70 & 1.70 & 0.30 & 0.15 & 0.94 & 1.75 & 1.71 & 0.21 & -1.36 & 3.35 & -0.98 & 0.44 & 0.08 & -0.19 & 1.02 & -0.24 & 1.79 & 1.87 & 17.14 \\
\hline $2 \mathrm{~A}$ & - & - & - & - & - & - & - & - & - & - & - & - & - & - & - & 0.21 & - & & 0.74 & 1.81 & 2.76 \\
\hline 3 & 0.28 & 0.62 & 0.3 & 0.13 & 0.36 & 0.41 & 0.60 & 0.50 & 0.66 & 0.58 & 1.28 & 0.39 & 0.18 & 0.25 & 0.78 & -0.09 & 0.54 & 0.09 & 0.49 & 0.04 & 8.39 \\
\hline 4 & -0.20 & 1.03 & 0.57 & 0.32 & 0.29 & 0.34 & 0.31 & 0.67 & 0.30 & 0.66 & 0.23 & 0.28 & 0.12 & 0.02 & 0.38 & 0.15 & 0.21 & -0.02 & 0.25 & 0.35 & 6.26 \\
\hline 4-A & 0.19 & 0.41 & 0.25 & 0.25 & 0.36 & 0.44 & 0.37 & 0.18 & 0.20 & 0.18 & 0.41 & 0.39 & 0.21 & 0.37 & 0.52 & 0.16 & 0.75 & 0.39 & 1.33 & 0.28 & 7.64 \\
\hline 4-B & 0.20 & 0.25 & 0.05 & 0.40 & 0.34 & 0.31 & 0.38 & -0.10 & -0.18 & 1.12 & -0.07 & 0.43 & 0.04 & 0.47 & 0.55 & 0.10 & 1.20 & 0.44 & 1.15 & 0.01 & 7.09 \\
\hline 5 & 0.16 & 0.94 & 0.60 & 0.60 & -0.98 & 0.21 & 0.03 & 3.19 & -0.10 & -0.35 & 0.18 & -0.40 & 3.34 & -0.22 & 0.66 & 0.25 & 0.72 & 0.05 & 5.94 & -0.63 & 14.19 \\
\hline $5-A$ & 0.39 & 0.02 & 0.41 & -0.42 & 0.49 & 0.31 & 0.79 & -0.01 & 0.27 & 0.75 & -0.20 & 0.14 & 0.13 & 0.28 & 0.40 & 0.05 & 0.71 & 0.15 & 0.13 & 1.31 & 6.1 \\
\hline $5-B$ & 0.32 & 0.63 & 0.55 & 0.40 & 0.04 & 0.41 & 0.63 & 0.29 & 0.02 & 0.65 & -0.49 & 1.08 & 0.03 & 0.39 & 0.56 & 0.14 & 0.88 & 0.60 & 1.39 & 0.14 & 8.66 \\
\hline 6 & -0.14 & 0.44 & 0.16 & 0.12 & 0.84 & 1.18 & 0.96 & 1.91 & 1.58 & 2.43 & 0.57 & 2.80 & 0.35 & 0.93 & 0.59 & -0.42 & 2.30 & 0.20 & 0.51 & 0.3 & 17.61 \\
\hline 7 & 0.22 & 1.38 & 0.74 & 0.40 & 0.91 & 0.85 & 2.14 & 1.30 & 1.51 & 1.50 & 0.45 & 1.20 & 1.23 & -0.18 & 0.38 & 0.90 & 0.80 & 0.73 & 0.41 & 0.43 & 17.3 \\
\hline 8 & 0.09 & 1.31 & -0.20 & 0.78 & 0.00 & 0.98 & 0.75 & -0.71 & 1.15 & 0.37 & 0.83 & 0.74 & 0.13 & 0.00 & 0.14 & -0.28 & 0.79 & -0.15 & 0.60 & -0.22 & 7.1 \\
\hline 9 & 1.49 & 1.01 & 1.06 & 0.98 & 0.71 & 1.10 & 2.17 & -0.51 & 0.91 & 1.51 & 0.07 & 0.47 & 0.34 & 1.53 & 0.53 & 0.46 & 0.26 & -0.10 & 0.25 & 0.21 & 14.45 \\
\hline $10 / 10 \mathrm{~A}$ & 0.10 & 0.33 & 0.04 & 1.57 & 0.57 & -0.02 & 1.73 & 0.13 & 0.60 & 0.66 & 0.49 & 0.74 & 1.38 & 3.42 & -2.52 & -0.18 & 1.10 & -1.04 & 2.10 & 0.84 & 12.04 \\
\hline 11 & 0.09 & 1.57 & 0.05 & 0.75 & 0.74 & -0.37 & 0.63 & 0.84 & -0.05 & 0.21 & 1.44 & 0.62 & 0.14 & -1.20 & 2.20 & 0.12 & 0.91 & 0.21 & 1.53 & - & 6.43 \\
\hline 12 & 1.51 & 1.14 & 0.53 & 0.33 & 0.32 & 0.66 & 0.95 & 0.94 & 0.91 & 0.55 & 0.81 & 2.21 & 0.77 & -0.50 & 1.61 & 0.65 & 0.04 & 0.07 & 1.75 & 0.97 & 11.4 \\
\hline 13 & 0.84 & 1.41 & 1.01 & 0.89 & 0.68 & 0.02 & 2.14 & -0.13 & 2.29 & 1.16 & 1.20 & 1.71 & 0.84 & -2.67 & 3.28 & -1.37 & 1.25 & 0.46 & 1.01 & - & 15.25 \\
\hline 14 & 0.72 & 1.88 & 1.96 & 1.96 & 1.32 & 0.66 & 3.32 & 2.58 & 0.20 & 2.61 & 5.03 & 0.08 & 10.94 & 0.65 & 1.03 & 0.02 & 0.86 & 0.67 & 0.81 & -4.85 & 32.45 \\
\hline $14 \mathrm{~A}$ & - & - & - & - & - & - & - & - & - & - & - & - & - & - & - & 1.87 & 0.79 & 1.71 & 1.03 & 7.06 & 12.46 \\
\hline 15 & 1.91 & 1.69 & 1.03 & 1.02 & 0.57 & 0.66 & 3.40 & 1.32 & 1.54 & 1.30 & 0.48 & 1.11 & 1.22 & 0.87 & -0.27 & 2.14 & 2.38 & 1.31 & 3.09 & 0.59 & 27.36 \\
\hline
\end{tabular}

*Positive values indicate recession; $*$ Negative values indicate an advance 


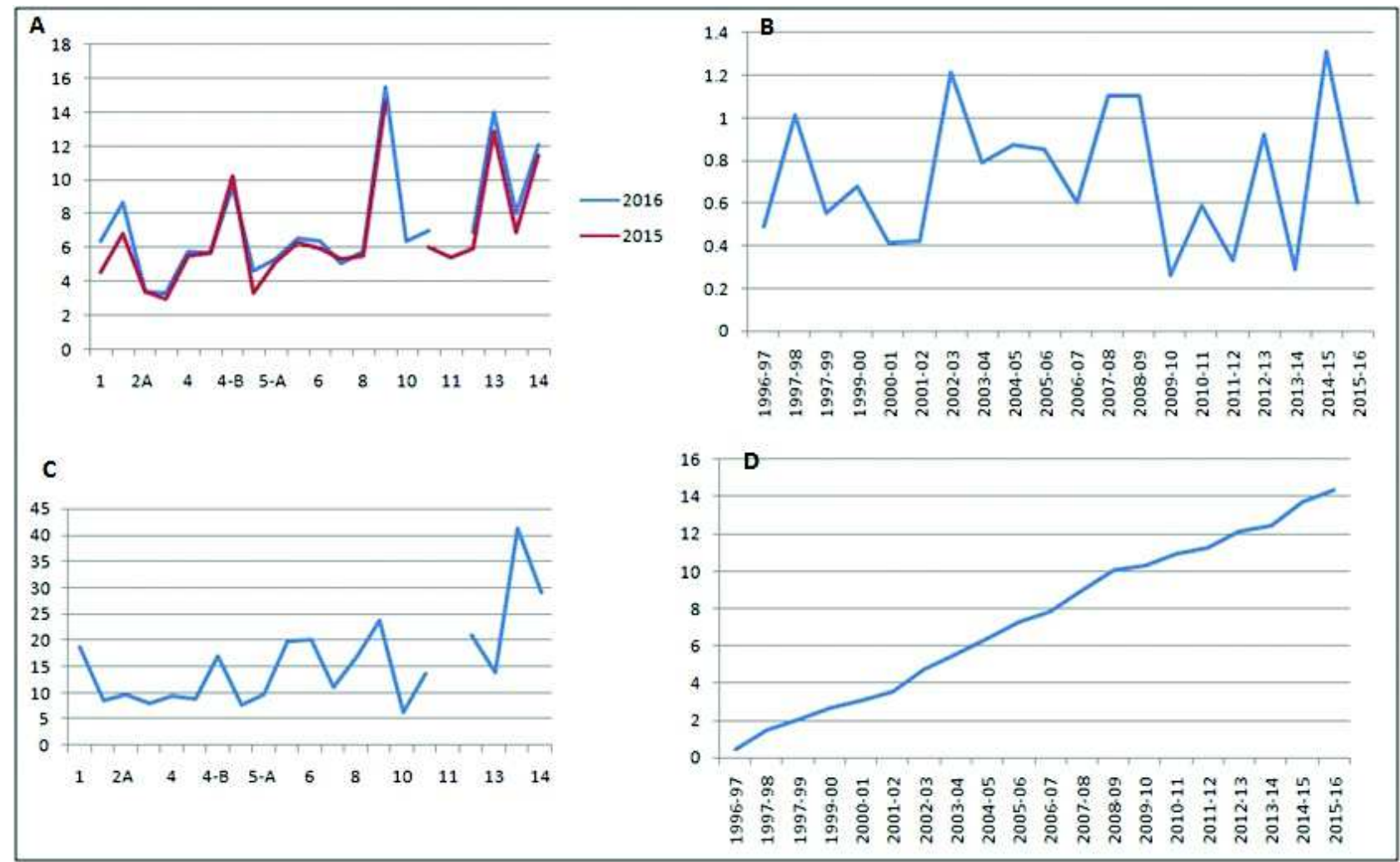

Fig. 2: Pattern of the DakshinGangotri (DG) glacier snout's recession. (A) Recession of the DG glacier in the years 2015 and 2016, (B) Recessional pattern since year 1996, (C) Total recession of DG snout since year 1996, (D) Cumulative curve for the recession of DG snout since 1996
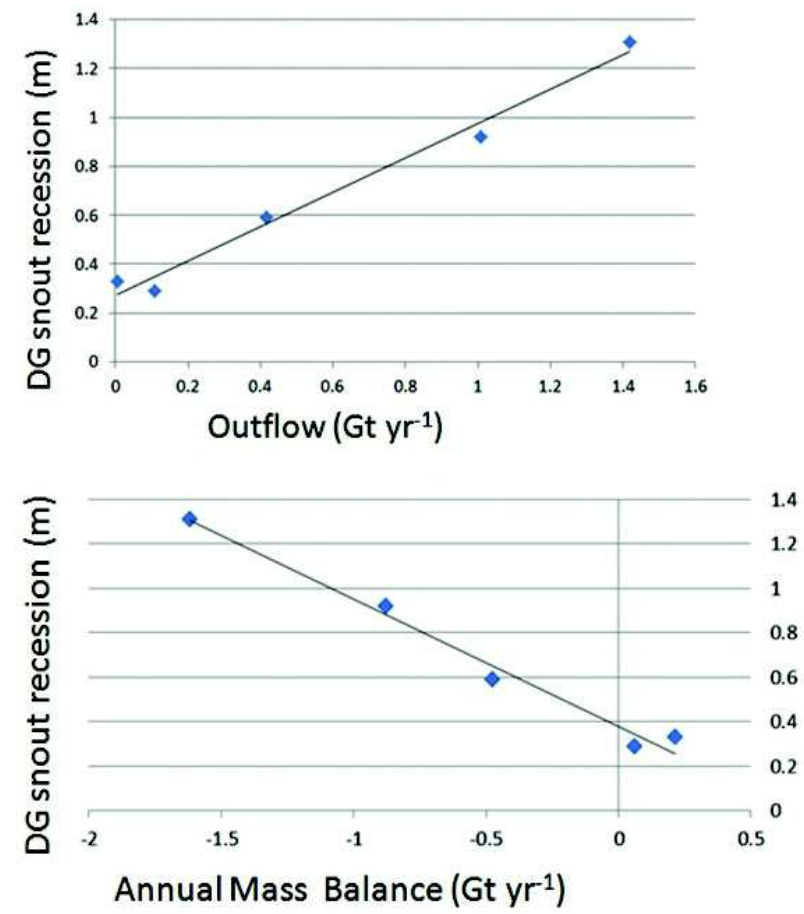

Fig. 3: Correlation between recession of DG snout with mean annual runoff and with annual mass balance of the area
Table 3: Cumulative recession of the DG glacier snout

\begin{tabular}{lcc}
\hline Period & Recession $(\mathrm{m})$ & Cumulative recession $(\mathrm{m})$ \\
\hline $1996-97$ & 0.49 & 0.49 \\
$1997-98$ & 1.01 & 1.50 \\
$1998-99$ & 0.55 & 2.05 \\
$1999-00$ & 0.68 & 2.73 \\
$2000-01$ & 0.41 & 3.14 \\
$2001-02$ & 0.42 & 3.56 \\
$2002-03$ & 1.21 & 4.76 \\
$2003-04$ & 0.79 & 5.55 \\
$2004-05$ & 0.87 & 6.42 \\
$2005-06$ & 0.85 & 7.28 \\
$2006-07$ & 0.60 & 7.88 \\
$2007-08$ & 1.10 & 8.98 \\
$2008-09$ & 1.10 & 10.08 \\
$2009-10$ & 0.26 & 10.34 \\
$2010-11$ & 0.59 & 10.93 \\
$2011-12$ & 0.33 & 11.26 \\
$2012-13$ & 0.92 & 12.18 \\
$2013-14$ & 0.29 & 12.47 \\
$2014-15$ & 1.31 & 13.78 \\
$2015-16$ & 0.6 & 14.38 \\
\hline
\end{tabular}


flank of DG snout. The wall lies on the higher ground compared to DG snout and receives maximum sun light throughout the day. This wall is being monitored continuously since 2001 with respect to fixed observation points located on the ground. The data on recessional pattern of Western wall has shown four advancements between 2007 and 2014 (Table 4 and 5). This pattern is totally different with the pattern of DG snout. Again after comparing with the average annual surface air temperature, the recession of Western wall does not show any direct correlation. The average annual recession between 2014 and 2015 is $2.37 \mathrm{~m}$. Recession at different observation points vary in magnitude with the western points showing larger retreat which gradually reduces towards east (Fig. 4).

\section{Snow Accumulation/Aablation on Ice Sheet}

Snow accumulation and ablation is measured by stake networks fixed on the Antarctic ice sheet, south of Schirmacher Oasis and on ice shelf near the India
Bay region. Stakes are fixed in a grid pattern with an interval of $50 \mathrm{~m}$ between two stakes. During the early phases of the austral summer period of 2014-15, a thick pile of snow accumulation took place in the study area. Unlike the data taken during the previous years, the measurements carried out in 2015 show that there was net ablation of $66.07 \mathrm{~cm}$ of snow from January 2014 to December 2014; the months January and February 2015 showed a net ablation of $9.40 \mathrm{~cm}$ and net accumulation of $7.61 \mathrm{~cm}$, respectively (Fig. 5). The annual average accumulation / ablation data of this area (2014 to 2015) shows a net ablation of 66.20 $\mathrm{cm}$. The past two years data shows annual accumulation of $56 \mathrm{~cm}$ for 2011-2012, $32.6 \mathrm{~cm}$ for 2012-2013, and $42.86 \mathrm{~cm}$ for 2013-2014. During the period of 2014 and 2015, a total of $66.20 \times 10^{4} \mathrm{~kg}$ of snow is ablated from the area encompassed by the stake network on the Polar ice sheet, making unit ablation of $-16.55 \mathrm{~kg} / \mathrm{m}^{2}$. For the period of $2015-16$ the larger area south of SchirmacherOasis shows $4 \pm 1 \mathrm{~cm}$ mean ablation. The annual mass balance of

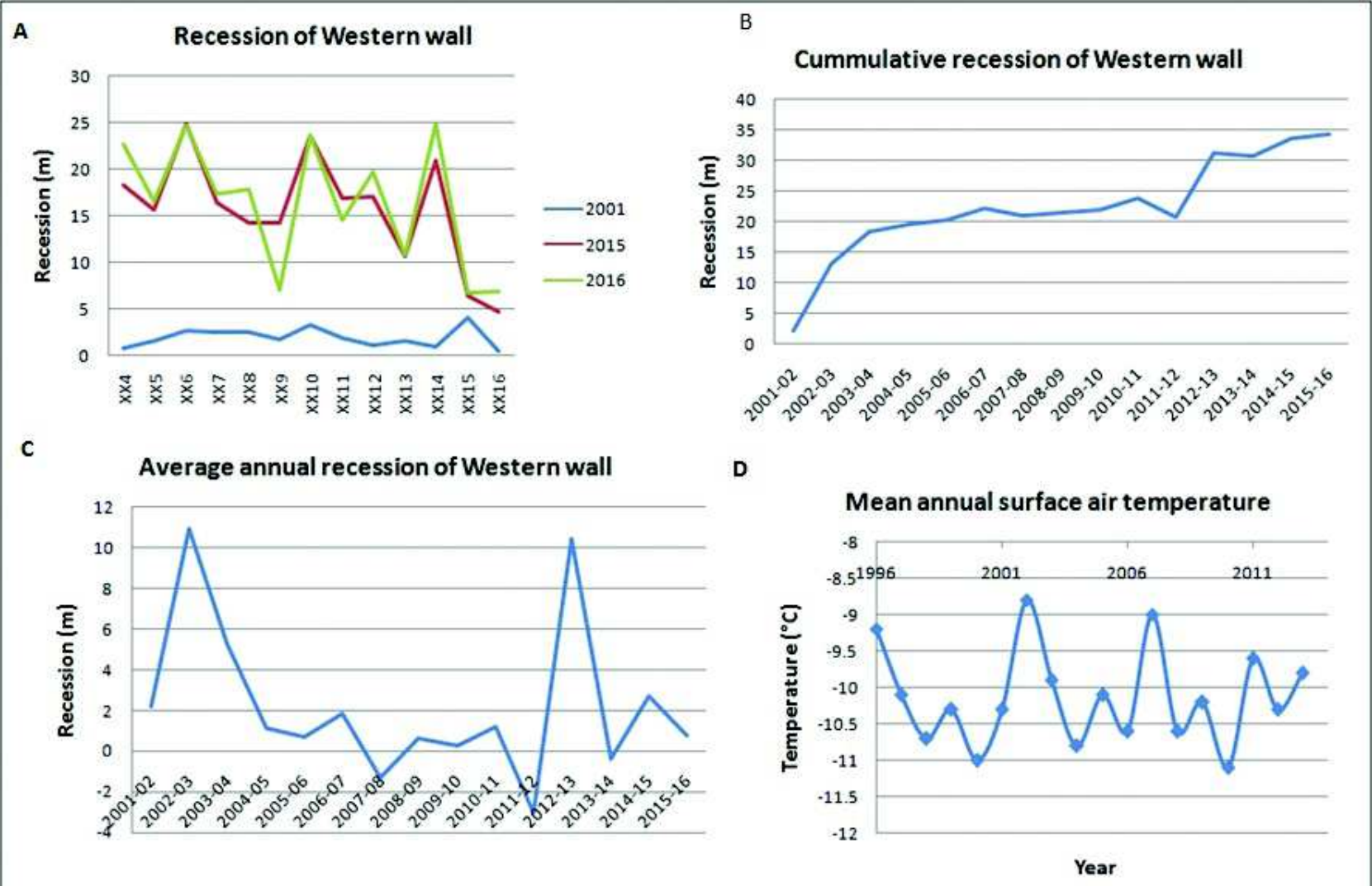

Fig. 4: Pattern of Western wall's recession. (A) Recession of Western wall in the years 2001, 2015 and 2016, (B) Cumulative curve for the recession of Western wall since 2001, (C) Recessional pattern since year 2001, (D) Average annual surface air temperature of the area 


\section{Table 4: Western Wall measurement (in meters) observation points since 2001}

\begin{tabular}{|c|c|c|c|c|c|c|c|c|c|c|c|c|c|c|c|c|c|c|}
\hline $\begin{array}{l}\text { Fixed } \\
\text { points }\end{array}$ & $\begin{array}{l}\text { Latitude } \\
\text { (S) }\end{array}$ & $\begin{array}{l}\text { Longitude } \\
\text { (E) }\end{array}$ & Feb-01 & Feb-02 & Feb-03 & Feb-04 & Feb-05 & Feb-06 & Feb-07 & Feb-08 & Feb-09 & Feb-10 & Feb-11 & Feb-12 & Feb-13 & Feb-14 & Feb-15 & Feb-16 \\
\hline XX2 & $70^{0} 44.603^{\prime}$ & $11^{0} 26.390^{\prime}$ & 1.06 & 3.20 & 44.10 & - & 46.15 & - & 30.50 & - & 52.76 & 51.65 & 54.48 & 45.30 & 89.00 & 52.85 & 48.62 & - \\
\hline XX3 & $70^{0} 44.621$ & $11^{0} 26.529$ & 0.95 & 0.86 & 58.50 & 72.50 & - & - & 28.60 & - & 41.31 & 59.25 & 58.60 & 56.10 & 127.4 & 77.25 & 90.79 & - \\
\hline XX 4 & $70^{0} 44.729^{\prime}$ & $11^{0} 27.660^{\prime}$ & 0.78 & 0.65 & 1.44 & 18.65 & 21.65 & - & 20.25 & - & 21.83 & 22.60 & 21.05 & 23.35 & 22.86 & 21.43 & 18.25 & 22.65 \\
\hline XX 5 & $70^{0} 44.797$ & $11^{0} 28.147^{\prime}$ & 1.53 & - & - & - & - & 13.95 & 14.15 & - & 16.28 & 16.60 & 16.90 & 10.40 & 13.44 & 15.11 & 15.69 & 16.55 \\
\hline XX 6 & $70^{0} 44.879^{\prime}$ & $11^{0} 28.562^{\prime}$ & 2.67 & - & 7.78 & 15.00 & - & - & 21.20 & - & 30.00 & 27.85 & 24.20 & - & 13.66 & 16.41 & 24.85 & 24.74 \\
\hline XX 7 & $70^{0} 44.932$ & $11^{0} 28.905$ & 2.53 & 5.01 & 5.24 & 6.80 & - & 8.56 & 11.13 & - & 18.45 & 11.87 & 12.20 & 12.34 & 13.78 & 13.84 & 16.38 & 17.43 \\
\hline XX 8 & $70^{0} 45.225$ & $11^{0} 31.120^{\prime}$ & 2.50 & 2.45 & 6.52 & 8.28 & - & 11.70 & 16.75 & 15.47 & 11.76 & 21.00 & 17.38 & 12.00 & 20.00 & 13.86 & 14.14 & 17.84 \\
\hline XX 9 & $70^{0} 45.268^{\prime}$ & $11^{0} 31.401$ & 1.72 & 2.47 & - & 3.00 & - & - & 22.70 & 5.30 & 16.93 & 6.73 & 6.50 & 5.29 & 6.10 & 5.98 & 14.23 & 7.09 \\
\hline XX 10 & $70^{0} 45.300^{\prime}$ & $11^{0} 31.614^{\prime}$ & 3.30 & 16.71 & 8.91 & 17.63 & 17.00 & 19.12 & 20.05 & 18.72 & 4.96 & 21.08 & 21.35 & 21.11 & 21.80 & 23.8 & 23.60 & 23.59 \\
\hline XX 11 & $70^{0} 45.417^{\prime}$ & $11^{0} 33.135^{\prime}$ & 1.84 & 4.37 & 5.27 & 5.92 & 7.10 & 7.30 & 9.70 & 10.75 & 19.73 & 10.24 & 10.73 & 9.83 & 13.00 & 9.40 & 16.82 & 14.64 \\
\hline XX 12 & $70^{0} 45.428^{\prime}$ & $11^{0} 33.289^{\prime}$ & 1.08 & - & 2.78 & - & 2.80 & $\sim 3.35$ & 5.90 & 9.76 & 10.94 & 10.40 & 8.42 & 13.23 & 15.92 & 15.35 & 16.97 & 19.76 \\
\hline XX 13 & $70^{0} 45.407^{\prime}$ & $11^{0} 33.478^{\prime}$ & 1.58 & 1.86 & 2.96 & 3.10 & 4.70 & 4.73 & 6.10 & 7.96 & 11.55 & 6.20 & 18.90 & 7.53 & 8.63 & 8.54 & 10.66 & 10.78 \\
\hline XX 14 & $70^{0} 45.403$ & $11^{0} 33.619^{\prime}$ & 1.02 & 1.87 & 2.66 & 3.80 & 5.65 & $\sim 6.50$ & 8.20 & 12.5 & 9.21 & 14.85 & 15.92 & - & - & 20.88 & 20.86 & 24.82 \\
\hline XX 15 & $70^{0} 45.424^{\prime}$ & $11^{0} 33.733^{\prime}$ & 4.06 & - & 4.42 & 4.80 & 4.37 & 4.47 & 4.90 & - & 13.52 & 5.43 & 4.50 & 5.58 & 5.04 & 5.78 & 6.40 & 6.81 \\
\hline XX 16 & $70^{0} 45.436^{\prime}$ & $11^{0} 34.022^{\prime}$ & 0.53 & - & - & 0.01 & 1.55 & 2.60 & 4.40 & - & 4.86 & 2.44 & 14.90 & 4.54 & 5.48 & 5.82 & 4.66 & 6.98 \\
\hline XX 17 & $70^{0} 45.631^{\prime}$ & $11^{0} 34.739^{\prime}$ & 0.94 & - & 1.54 & - & 20.05 & - & - & - & - & - & 16.78 & - & - & & & \\
\hline
\end{tabular}

“_, points not available/snow covered
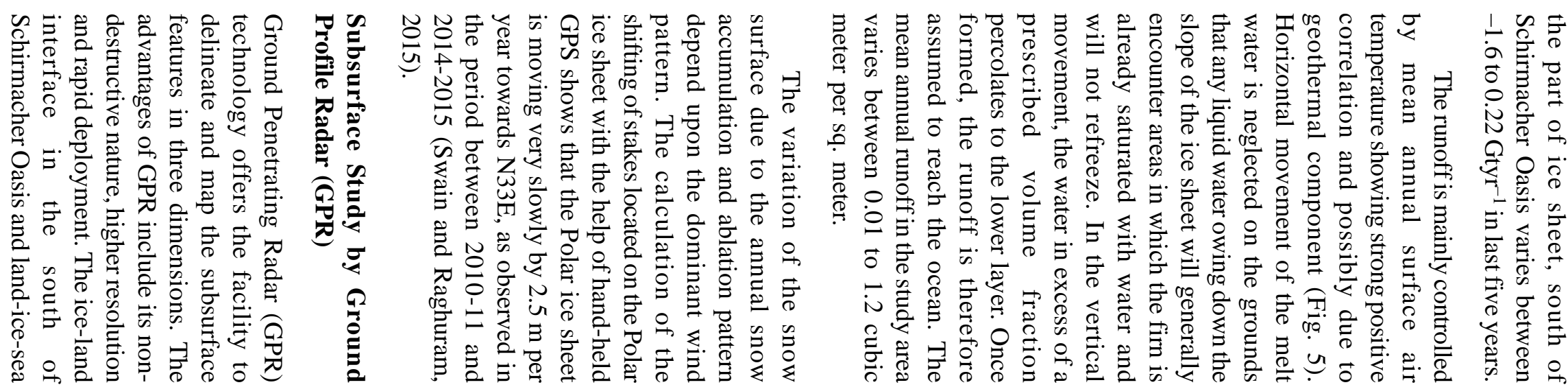


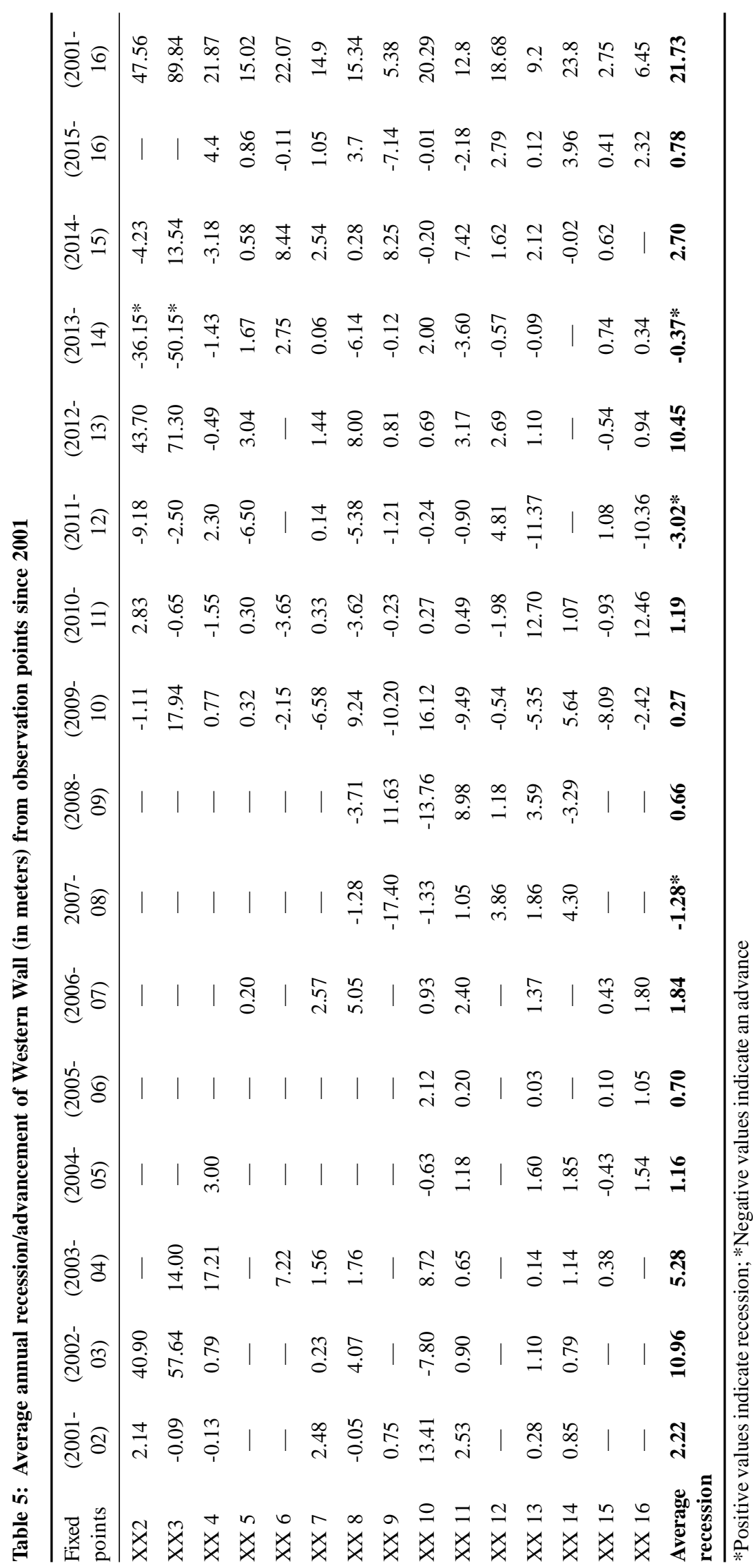

interface along the northern margin of the Schirmacher Oasis has been carried out (Fig. 6) which is very crucial for the study of mass balance of this region. During expeditions, A $60 \mathrm{~m}$ line was surveyed (MLF at $35 \mathrm{MHz}$ ) at a distance of $90 \mathrm{~m}$ north of Baalsrudfjelletnunatak to $150 \mathrm{~m}$ distance north, showed that the variation in land-ice interface at a depth of $50 \mathrm{~m}$ to $90 \mathrm{~m}$. Another 60 $\mathrm{m}$ profile obtained (MLF at 35 $\mathrm{MHz}$ ) from $190 \mathrm{~m}$ north of this nunatak to $250 \mathrm{~m}$ north of it show the variation in land-ice interface at a depth of $140 \mathrm{~m}$ to $180 \mathrm{~m}$. A combined profile from the base of Baalsrudfjelletnunatak to $250 \mathrm{~m}$ north shows a uniform and moderate slope of 280 till initial 70 $\mathrm{m}$, followed by a steep slope of 380 till $250 \mathrm{~m}$. Further GPR profiles obtained beyond these points show that the depth of the Land-ice interface increased to $300 \mathrm{~m}$ at a horizontal distance $500 \mathrm{~m}$ away from Baalsrudfjelletnunatakand at a distance of $750 \mathrm{~m}$, a more or less uniform thickness of ice is observed for about 330-350 m till the point A7 of the Indianconvoy route. To observe still deeper part, two way travel time was increased to $6000 \mathrm{~ns}$ range, which is an equivalent to a depth of $440 \mathrm{~m}$. Thereafter, the survey line followed the convoy route closely and subsurface data was recorded from A-7 (70 $52.772^{\prime} \mathrm{S}$ : $12^{\circ} 8.550^{\prime}$ E) to A-12 $\left(70^{\circ} 50.393^{\prime} \mathrm{S}\right.$ : $\left.12^{\circ} 18.492^{\prime} \mathrm{E}\right)$. Data indicates that the polar ice thickness increases from $0 \mathrm{~m}$ near Baalsrudfjellet nunatak to about $380 \mathrm{~m}$ at point A-12 of convoy route (Dharwadkar et al., 2012).

A possible loci for L-I-S (Land-Ice-Sea) interface was 


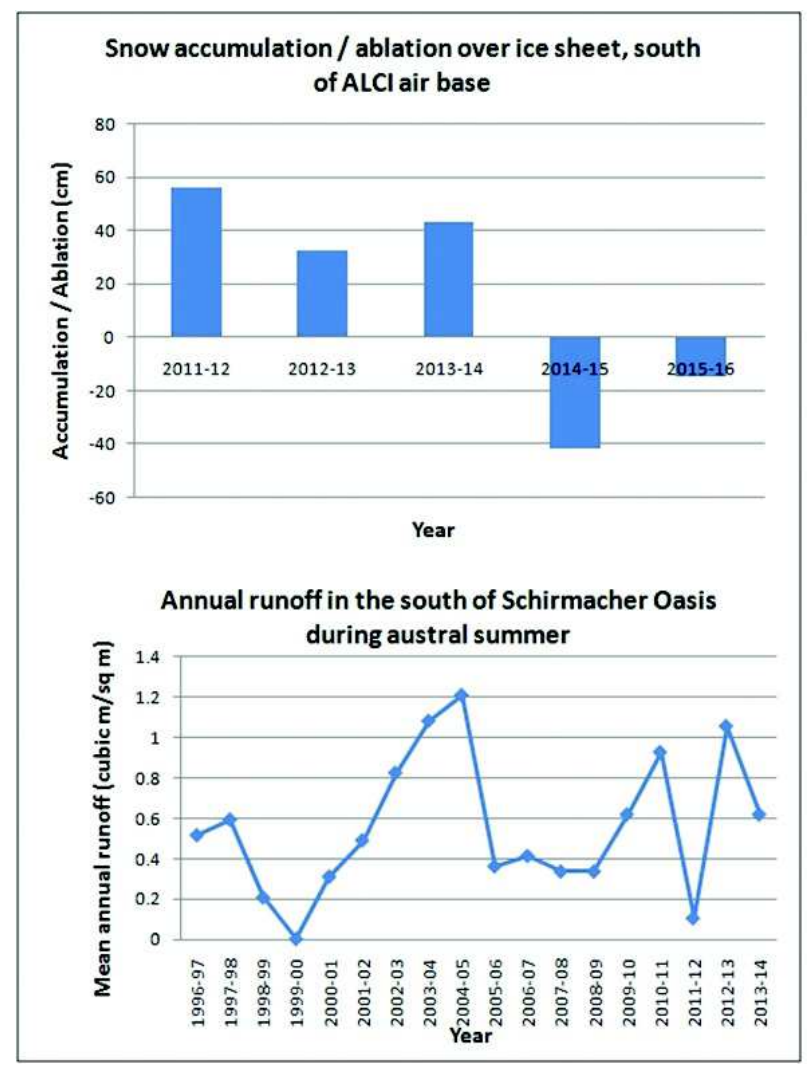

Fig. 5: Average annual snow accumulation/ablation and runoff, south of Schirmacher Oasis

detected at latitude $70^{\circ} 51.090^{\prime} \mathrm{S}$ and longitude $12^{\circ} 14.429^{\prime} \mathrm{E}$ that gets expressed as a steeply sloping land-ice interface juxtaposed against gently sloping sea-ice interface. This juxtaposition is observed at $340 \mathrm{~m}$ below the ice sheet that was later confirmed in a closely spaced profile line generated during 30th expedition. Convex nature of the bedrock has been observed in one profile north of the grounding line.

\section{Glacial Inventory of the Wohlthat Mountains}

A glacial inventory of the Wohlthat Mountains was prepared as per the guidelines of the Manual of Temporary Secreteriat (TTS) of World Glacier Inventory (Muller, 1977, 1978). The Wohlthat Mountain, located $110 \mathrm{~km}$ south of Schirmacher Oasis in Dronning Maud Land, comprises four blocks as (i) Gruber, (ii) Petermann, (iii) Humboldt and (iv) Orvin. There are total 122 glaciers in Wohlthat mountain chain. Out of this, more than $50 \%$ of the glaciers are oriented in NW and W directions. Most of the glaciers are smaller than $1 \mathrm{sq} \mathrm{km}$. In general the glacier elevation varies between 700 to $2600 \mathrm{~m}$ above sea level. The glaciers are of mountain glacier type occurring in the form of ice aprons or flowing in simple basin. The general elevation of outlet glacier Oasiss from 1900 metre above sea level (masl) in the north in the Gruber block. Within the ambit of glacierisation of Gruber, 19 glaciers of different orientation and dimension were identified. The general elevation of the outlet glacier is $2300 \mathrm{msl}$ in the south to $1000 \mathrm{msl}$ in the north in Petermann block. There are 45 glaciers in this group. In Humboldt group the general elevation of outlet glacier (and ice sheet) is 2100 masl in the south to 1000 masl in the north. There are 41 numbers of glaciers in this group. In the Orvin group there are 17 glaciers and the general elevation $2100 \mathrm{~m}$ to $1700 \mathrm{~m}$ from south to north (Srivastava et at., 1988). Studies of recessional moraines indicate that the deglaciation in the eastern part of Wohlthat Mountain has taken place in three stages leading to the formation of dry valleys. The presence of ice sheet at $2000 \mathrm{~m}$ above sea level is indicated by polished surfaces and striations. These striations imply northwesterly flow of the glaciers.

\section{Ice Sheet Dynamics}

During $22^{\text {nd }}(2002-03)$ and $24^{\text {th }}(2004-05)$ Indian Antarctic Expeditions, study was carried out to understand the movement of glacier surrounding the Schirmacher Oasis in collaboration with Indian Institute of Geomagnetism (IIG), Mumbai (Fig. 7). The GPS network in the south of Schirmacher Range with 21 sites (Fig. 7) having $5 \mathrm{~km}$ inter-space networking was established to measure the horizontal movement of ice sheet. The base station (MAIT) was set up on exposed bedrock on Schirmacher Oasis. The GPS receivers in the field were powered by specially sealed $12 \mathrm{~V}, 72 \mathrm{Ah}$ charged batteries enclosed in non conducting boxes. All the sites were observed continuously for 48-72 hours duration with $30 \mathrm{~s}$ sampling interval and $15^{\circ}$ elevation mask. The recorded GPS data organized into $24 \mathrm{~h}$ segments, covered a Universal Time Coordinated (UTC) day and were analysed in three steps. In the first step the GPS carrier phase data were processed with the precise ephemeris from the International GPS Service (IGS) stations to produce position estimates. In the next step these data have been standardize with the help of daily solutions for station positions using GPS analysis Massachusetts Institute of Technology (GAMIT) and software (King and Bock, 2000). In 

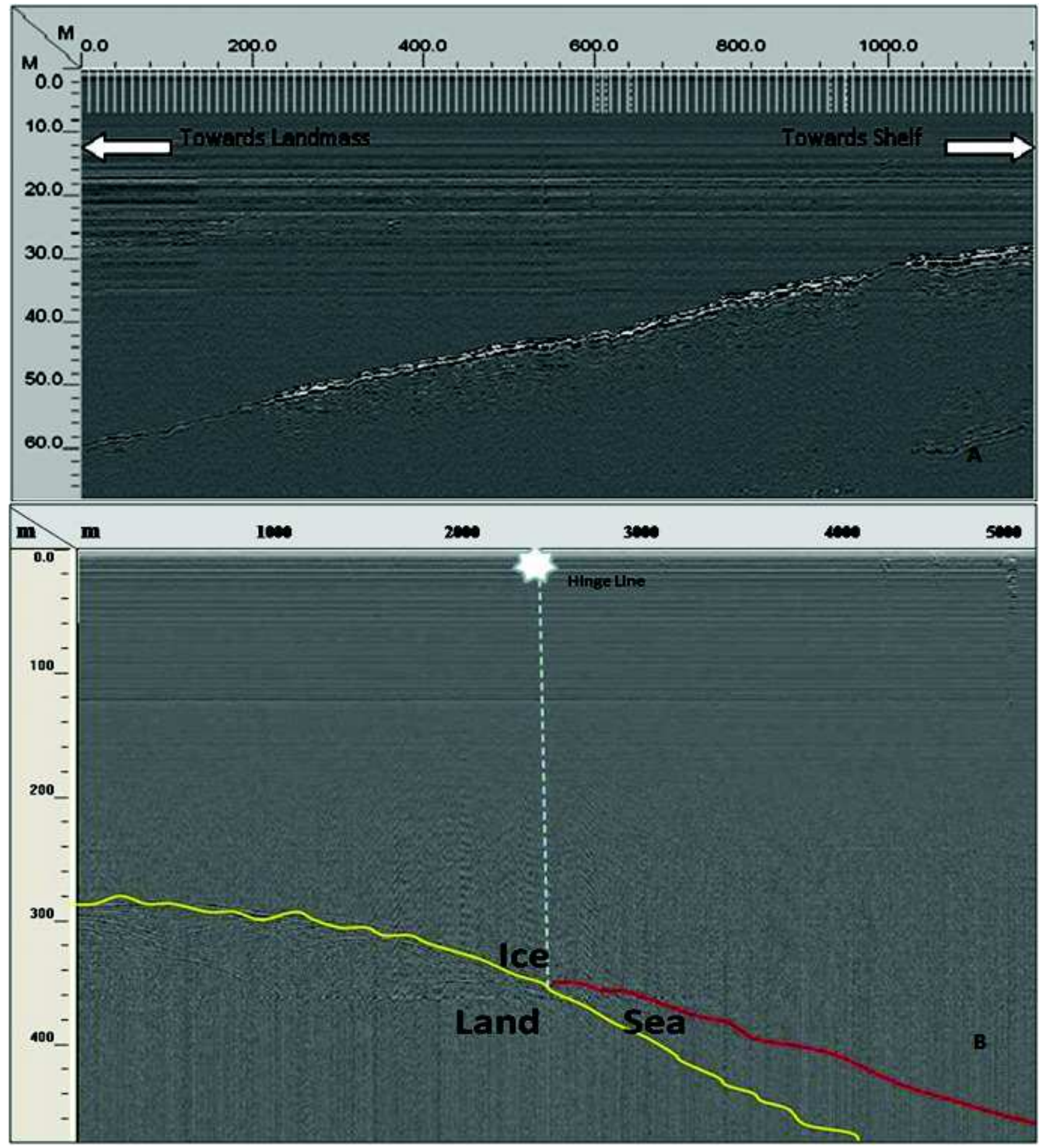

Fig. 6: (A) Interface between Ice and Land between Baalshrudnunatak and A-12 point, (B) Land-Ice-Sea interface, East of Schirmacher oasis

the third step station position and velocity vectors at each site were obtained.

For a complete description of the flow field of a glacier, both the horizontal and vertical components of the velocity are required. However, this study was confined to calculate the horizontal velocity components only by imposing tight constraints $(1 \mathrm{~cm} /$ a) on the horizontal components of the base station. Horizontal velocities of the glacier sites lie between $1.89 \pm 0.01$ and $10.88 \pm 0.01 \mathrm{~m}$ a- 1 to the north-northeast, with an average velocity of $6.21 \pm 0.01 \mathrm{~m} \mathrm{a}^{-1}$. The 


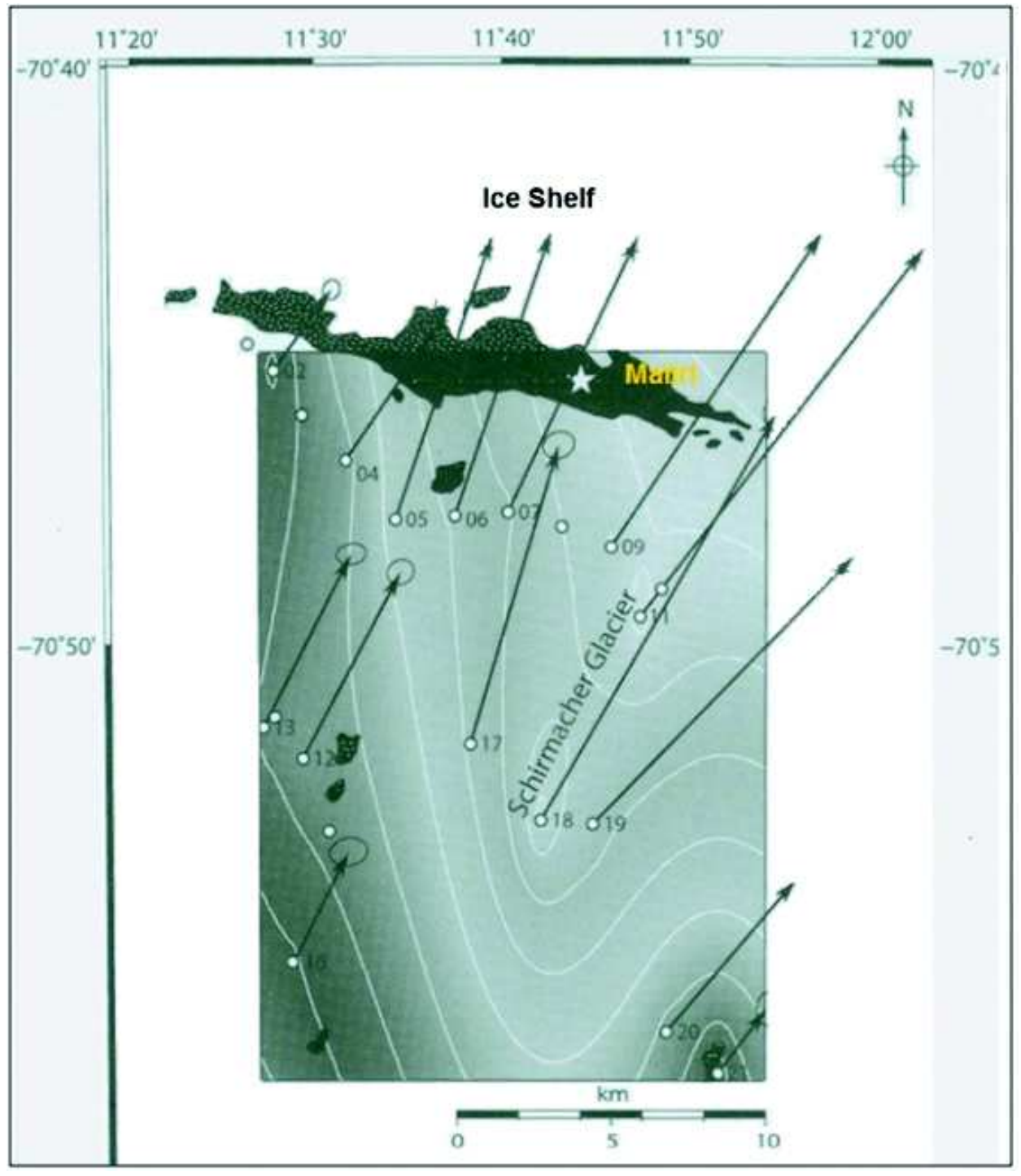

Fig. 7: Ice Sheet dynamics surrounding the Schirmacher Oasis, East Antarctica

principal strain rates provide a quantitative measurement of extension rates, which range from $(0.11 \pm 0.01) \&$ times $10-3$ to $(1.48 \pm 0.85) \times 10-3 \mathrm{a}-1$, and shortening rates, which range from $(0.04 \pm 0.02)$ $\times 10-3$ to $(0.96 \pm 0.16) \times 10-3$ a- 1 . The velocity and strain-rate distributions across the GPS network in the ice sheet, south of Schirmacher Oasis are spatially correlated with topography, subsurface undulations, fracture zones/crevasses and the partial blockage of the flow by nunataks and the Schirmacher Oasis (Sunil et al., 2007, 2010).

In a related study, the movement of ice sheet was also observed on year long basis through one polar winter. The vector movement of the glacier helps in bulging forward in the snout area of Dakshin
Gangotri glacier. These extra bulged parts of the snout break down and melt away from the main glacial body during the polar summer resulting in a net retreat of the glacier (Chaturvedi et al., 1999, 2003 and 2004).

\section{Discussions and Conclusion}

The Dakshin Gangotri (DG) snout which is a part of EAIS, overriding Schirmacher Oasis, shows continuous recession since last three decades. During the period 2014-15, the DG glacier snout has receded by $1.31 \mathrm{~m}$ with respect to its position from previous year. For the same period, the western wall has shown a recession of $2.37 \mathrm{~m}$ with respect to the previous year. It is observed that meteorological parameters including higher average annual surface air 
temperature and higher wind speed results in greater recession of the snout of DG glacier snout in the succeeding year. The annual recessional pattern of Dakshin Gangotri glacier snout indicates that major recession in every five years with minor peaks at every 2-3 years interval between 1996-2010 period. But in the last five years (2011-16) the trend of DG snout is different than the previous 15 years period. The recessional pattern of Western wall is totally different with the pattern of DG snout. During the period of 2014 and 2015 , there is unit ablation of $-16.55 \mathrm{~kg} / \mathrm{m}^{2}$ over ice sheet, south of Schirmacher Oasis. The mean annual runoff in the study area varies between 0.01 to $1.2 \mathrm{~m}^{3}$ per sq. meter. This mean annual runoff shows direct positive correlation with the average annual recession of the snout. The annual mass balance of the part of ice sheet, south of Schirmacher Oasis varies between -1.6 to $0.22 \mathrm{Gtyr}^{-1}$ in last five years. The minor correlation between surface air temperature anomaly of Schirmacher region along with global (southern and northern hemisphere) temperature anomaly pattern provides space for some other factors such as effect of ocean current, albedo, isostacy and solar cycle, which may be contributing to the recession of this snout.

\section{References}

Beg M J, Chaturvedi A, D’Souza M J and Asthana R (1997) Fluctuations in the Surface Profile of a part of Ice Shelf in Central Dronning Maud Land, East Antarctica Scientific report of Thirteenth Indian Expedition to Antarctica Tech. Pub 11 DOD, Govt of India, New Delhi, 221-226

Chaturvedi A, Singh A and Kaul M K (2001) Ice core drilling in polar continental ice at Tronstadhallet, Central Dronning Maud Land, Antarctica; Proc. Symp. Snow, Ice and Glaciers, March 1999 Geolsurv Ind Spl Pub 53 403-408

Chaturvedi A, Singh A, Gaur M P, Krishnamurthy K V and Beg M J (1999) A confirmation of Polar Glacial Recession by monitoring the Snout of DakshinGangotri Glacier in Schirmacher Oasis. Scientific report on fifteenth Indian Expedition to Antarctica, Tech. Pub No. 13, D.O.D. Govt. of India, New Delhi, 321-336.

Chaturvedi A, Beg M J, Singh A and Ravindra R (2003) Two decades of obervations over polar ice cap margin in SchirmacherOasis of central Dronning Maud Land Antarctica, Abstract for 7th Int. Symposium of Antarctic Glaciology (ISAG-7) Milano, Italy
The ice-land interface in the south of Schirmacher Oasis indicates that the polar ice thickness increases from $0 \mathrm{~m}$ near Baalsrudfjellet nunatak (south east of Schirmacher Oasis) to about $380 \mathrm{~m}$ towards north-west of Schirmacher Oasis $\left(70^{\circ} 50.393^{\prime} \mathrm{S}\right.$ : $\left.12^{\circ} 18.492^{\prime} \mathrm{E}\right)$. There are total 122 glaciers in Wohlthat mountain chain. Out of this, more than $50 \%$ of the glaciers are oriented in NW and $\mathrm{W}$ directions. Most of the glaciers are smaller than $1 \mathrm{sq}$ $\mathrm{km}$. These glaciers partly contribute to the part of ice sheet south of Schirmacher Oasis. Thermal profiling of ice sheet shows that the variations in the polar cold front penetrated up to a maximum depth of $25 \mathrm{~m}$. Beyond this depth, the temperatures remained uniform throughout the year. The highest temperatures were recorded at the bottom of the glacier. The zone of temperature-inversion was observed between $25 \mathrm{~m}$ and $30 \mathrm{~m}$ depth. Beyond this zone, the temperature gradually kept on rising till the borehole reached the bedrock. Horizontal velocities of the glacier sites lie between $1.89 \pm 0.01$ and $10.88 \pm 0.01 \mathrm{~m} \mathrm{a}^{-1}$ to the northnortheast, with an average velocity of $6.21 \pm 0.01 \mathrm{~m}$ $\mathrm{a}^{-1}$.

Chaturvedi A, Beg M J and Keshav Prasad A V (2004) Monthly patterns of Advance and Retreat of DakshinGangotri glacier snout in Schirmacher Oasis, Ninteenth Indian Expedition to Antarctica, Scientific Report, DOD Tech Publ 17 21-31

Chaturvedi A, Shrivastava P K, Kaul M K, Chaturvedi S K and Mukerji S (2009) Recession of DakshinGangotri glacier snout in Schirmacher Oasis, East Antarctica Ind Jour of Geosc 63 229-234

Dharwadkar A, Swain A K, Chaturvedi A, Mandal A, Roy S K and Kumar P (2012) Delineation of grounding line, quantification of the expanse and thickness of the ice shelf near Schirmacher Oasis, East Antarctica, RP/CHQ/IRHR/ 2006/008, Geological Survey of India Reporting, R. W. and Bock, Y., 2000: Documentation for the GAMIT analysis software, release 10.0, Massachusettes Institute of Technology, Cambridge

King R W and Bock Y (2000) Documentation for the GAMIT analysis software, release 10.0, Massachusettes Institute of Technology, Cambridge

King R W and Bock Y (2000) Documentation for the GAMIT analysis software, release 10.0, Massachusettes Institute 
of Technology, Cambridge

Muller F, Caflisch T and Muller G (1977) Instructions for the compilation and assemblage of data for a world glacier inventory, Zurich, Temporary Technical Secreteriat for World Glacier Inventory, Swiss Federal Institute of Technology

Muller F, Caflisch T and Muller G (1978) Instructions for the compilation and assemblage of data for a world glacier inventory, Zurich, Temporary Technical Secreteriat for World Glacier Inventory, Swiss Federal Institute of Technology, Suppliment identification glacier number

Ravindra R, Chaturvedi A and Beg M J (2002) Melt water lakes of Schirmacher Oasis - Their genetic aspects and classification. In Advances in Marine and Antarctic Science. Eds. Sahoo, D.B. and Pandey, P.C. New Delhi, 301-303

Shrivastava P K, Asthana R, Beg M J, Nath A K, Dharwadkar A, Swain A K, Roy S K and Mandal A (2013) Latitudinal shift in iceberg distribution as observed along the voyage route of Indian Antarctic Expedition Indian Jour of Geosciences 66 149-158

Shrivastava P K, Asthana R and Roy S K (2011) The Ice Sheet Dynamics around DakshinGangotri Glacier, Schirmacher Oasis, East Antarctica vis-a-vis Topography and Meteorological Parameters Jour Geol Soc of Ind 78 117123

Shrivastava P K, Roy S K and Mallik R K (2014) Glaciological Studies in Central Dronning Maud Land, East Antarctica during the 33rd Indian Antarctic Expedition, GL/CHQ/M IV/2013/073, Geological Survey of India Report
Singh R K, Mukerji S, Srivastava D and Kaul M K (1988) Snow Accumulation and Ablation Pattern on Ice Shelf near DakshinGangotri, Antarctica and Development of Fast Ice off DakshinGangotri Sci Rep of Fifth Indian Expedition to Antarctica Tech Pub 5 DOD, New Delhi, 189-204

Srivastava D, Kaul M K, Singh R K, Mukerji S and Jayaram S (1988) Glacier inventory of Wholthat Mountain chain, Queen Maud Land, Antarctica Scientific Report, Dept of Ocean Development, Tech Pub 5 235-245

Sunil P S, Reddy C D, Ponraj M, Dhar A and Jayapaul D (2007) GPS determination of the velocity and strain rate fields on Schirmacher Glacier, central Dronning Maud Land, Antarctica Jour Glaciology 53 558-564

Sunil P S, Reddy C D, Dhar A, Ponraj M, Sevaraj C and Jayapaul D (2010) GPS derived velocity field and strain rates of Schirmacher Glacier, East Antarctica Scientific Report, Tech Publ 21 115-126

Swain A K and Roy S K (2011) Glaciological work carried out during $27^{\text {th }}$ Indian Antarctic Expedition. Unpublished report, Antarctica Division, (Mission IV) Geological Survey of India, pp 1-10

Swain A K and Mandal A (2012) Glaciological observations during the $30^{\text {th }}$ IndianAntarctic Expedition.Unpublished report, Antarctica Division, (Mission IV) Geological Survey of India, pp. 1-10

Swain A K and Raghuram (2015) Glaciological studies in Central Dronning Maud Land, East Antarctica during the $34^{\text {th }}$ Indian Antarctic Expedition, GL/CHQ/M-IV/2014/084, Geological Survey India. 